\section{Eksepsjonelle sykdomsforløp og alternativ behandling}

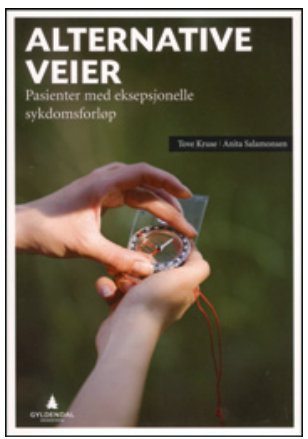

Tove Kruse, Anita Salamonsen Alternative veier

Pasienter med eksepsjonelle sykdomsforløp. 198 s, ill. Oslo: Gyldendal Akademisk, 2012 Pris NOK 375

ISBN 978-82-05-39523-7

Utgiver er Gyldendal Akademisk, hvilket skulle indikere at dette er en fagbok. Det er det ikke. Det er en samling av åtte sykehistorier, fortalt av pasientene selv med egne ord. De åtte skal representere eksepsjonelle sykdomsforløp, men ingen medisinske vurderinger er knyttet til deres historier. Alternative veier består av fire kapitler: sykehistoriene, forskning på eksepsjonelle sykdomsforløp, ulike organisasjoners refleksjoner og veien videre. Til tross for sitt beskjedne sidetall (198) og luftige layout er dette en relativt ordrik utgivelse.

Sykehistoriene utgjør to tredeler. De fleste er detaljrike, men det er noen mer kortfattede. Historiene er skrevet av pasientene selv i samarbeid med forfatterne.

Pasienthistoriene er valgt ut fra Register for eksepsjonelle sykdomsforløp (RESF), opprettet i 2002. Dette registeret er del av Nasjonalt forskningssenter innen komplementær og alternativ medisin (NAFKAM) ved universitetet i Tromsø. Forfatterne er forskere ansatt ved NAFKAM og RESF. Det dreier seg således ikke om gjennomsnittlige pasienterfaringer eller sykehistorier, de er i høyeste grad selektert. Seleksjonskriteriene er ikke oppgitt.

Pasientene har kreft, multippel sklerose (MS) eller kronisk utmattelsessyndrom/myalgisk encefalopati (CFS/ME). Det er alltid lærerikt å lese om pasienterfaringer. Mang en helsearbeider har fått en aha-opplevelse som pasient selv. Alle de åtte (seks norske og to danske) har to tydelige fellestrekk: De har ikke fått den hjelpen de ønsket seg i det offentlige helsevesenet og har gode erfaringer med alternativ behandling. Misnøyen gjelder manglende kontinuitet, dårlig organisering, fragmenterte pasientforløp, ansvarspulverisering, mye ventetid samt opplevelsen av et stresset arbeidsmiljø for de ansatte, med dertil hørende lite legekontakt og manglende individuell oppfølging. Sykehuset ble opplevd som en ganske kaotisk helsefabrikk der pasienten ikke ble ivaretatt som menneske. Pasientene opplevde et betydelig informasjonsproblem fordi de fikk forskjellig beskjed fra ulike leger, også når livsviktige avgjørelser skulle tas. Det inngir ikke tillit når beslutninger tilsynelatende virket tilfeldige. De følte seg derfor ikke trygge i sykehuset og syntes de selv måtte organisere utredning og behandling.

Dette i motsetning til de alternative behandlerne, som omga seg med en rolig og trygg atmosfære og alltid hadde tilstrekkelig med tid. Noen av bokens pasienter har kun fått alternativ behandling, andre har brukt et alternativt supplement til skolemedisinen. De siste hevder at det alternative opplegget har muliggjort det gode behandlingsresultatet. Styrket immunsystem er et felles mantra for den alternative behandlingen. Det er vanskelig å bedømme de åtte innleggene fordi det mangler medisinske nøkkelopplysninger. Forfatterne har heller ikke innhentet noen medisinske vurderinger til hver enkelt historie.

Informasjonen fra helsepersonell til pasient er ofte mangelfull. Bokens pasienter påpeker nettopp dette. Misforståelser er vanlig, og mange har et feilaktig bilde av sin sykdomssituasjon. Bedømt ut fra Alternative veier kan det synes som om NAFKAM og RESF kun passivt registrerer sykehistorier som pasienter sender inn. Det er overraskende at disse universitetsinstitusjonene tilsynelatende ikke kvalitetssikrer informasjonen som er brukt her. Denne utgivelsen må derfor leses som åtte subjektive opplevelser fra norsk og dansk helsevesen - uten at noen konklusjon kan trekkes om eksepsjonelt sykdomsforløp. Dette minner mest om ukebladenes pasienthistorier og kan forstås som et innlegg til støtte for bruk av alternativ behandling ved kreft, multippel sklerose og kronisk utmattelsessyndrom.

Hva kan vi lære? Hovedbudskapet er at det norske offentlige sykehusvesen kanskje har mistet noe vesentlig på veien mot stadig bedre behandlingsresultater. Dette «noe» er pasientomsorg og ansvar for det hele mennesket. Dette «noe» vil ny offentlig ledelse i sykehusvesenet aldri forstå fordi det ikke kan skrives inn i Excelark. De åtte pasienthistoriene peker på dårlig organisering og oppstykkede behandlingsforløp med liten følelse av trygghet i offentlige sykehus. Historiene representerer ikke noe gjennomsnitt, de er utvalgt. Alternative veier gir ikke særlig mer informasjon enn det man kan finne i ukebladene.

\section{Gunnar Tanum}

Oslo universitetssykehus

\section{Luftveisinfeksjoner i komprimert form}

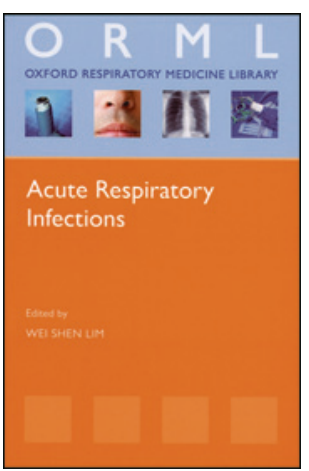

Wei Shen Lim, red Acute respiratory infections

127 s, tab, ill. Oxford: Oxford University Press, 2012. Pris GBP 20

ISBN 978-0-19-958808-4

Boken inngår i serien «Oxford Respiratory Medicine Library». Den er heftet og i lommeformat og henvender seg til leger som tar hånd om pasienter med akutte luftveisinfeksjoner, inkludert influensa og pasienter med nedsatt immunforsvar. De 14 forfatterne har skrevet 11 kapitler som i hovedsak omhandler infeksjoner i de nedre luftveier i en slik grad at bokens tittel grenser til å være misvisende. Gjensidig påvirkning av de øvre og nedre luftveier er ikke viet plass. Sjeldne og eksotiske lungeinfeksjoner er beskrevet. Vaksiner og bruk av antibiotika ved luftveisinfeksjoner er omtalt i egne kapitler.

Teksten er kortfattet og de viktigste opplysninger er oppsummert i faktabokser, tabeller og flytdiagrammer. Hvert kapittel avsluttes med anbefalt litteratur for videre lesning. Det blir da en mangel at en del referanser som det er henvist til i teksten, ikke er med $i$ litteraturlisten. Anbefalt behandling ved en del sykdommer kan avvike fra de tilsvarende norske anbefalinger. Noen behandlinger med usikker effekt og svakt evidensnivå er tatt med uten reservasjoner.

Formålet har vært å gi en kompakt og praktisk oversikt over akutte infeksjoner, spesielt i de nedre luftveier. Teksten retter seg mot en klinisk hverdag og patofysiologiske forhold er ikke omtalt. Stikkordregister og ensartet utforming av kapitlene gjør den lett å finne frem i. Noen skjemmende trykkfeil burde vært unngått. Boken kan anbefales ved å være oversiktlig med gode oppsummeringer og sjekklister som kan være et bidrag i pasientsikkerhetsarbeidet.

Hans H. Elverland

$\emptyset$ re-nese-halsseksjonen

Nordlandssykehuset Lofoten 